\title{
The inclusion of science process skills in multiple choice questions: Are we getting any better?
}

\author{
Ridvan Elmas ${ }^{1}$, George M. Bodner ${ }^{2}$, Bulent Aydogdu ${ }^{1}$, Yakup Saban ${ }^{1}$ \\ ${ }^{1}$ Department of Science Education, Afyon Kocatepe University, 03200, Afyon, TURKEY \\ 2Department of Chemistry, Purdue University, 560 Oval Drive, West Lafayette, IN 47907, USA \\ For correspondence: relmas@aku.edu.tr
}

\begin{abstract}
The goal of this study was to analyze the science and technology questions with respect to science process skills (SPS) included in the Transition from Primary to Secondary Education (TEOG) examination developed for use with $8^{\text {th }}$-grade students in Turkey. The 12 TEOG exams administered in the course of three academic years from 2014 through 2016 that included 238 science and technology questions were subjected to document analysis to determine whether the process is being made toward incorporating science process skills in this high-stakes exam. The number of science and technology questions that incorporated SPS increased from 49 in 2013-2014 to 53 in 2014-2015 and 76 in the most recent year, 2015-2016. These questions included interpretation and inference skills far more often $(n=59)$ than data processing/modeling/hypothesis skills $(n=2)$. The document analysis showed that basic science process skills were included in science and technology questions more or less as often as integrated science process skills.
\end{abstract}

Keywords: Science process skills, Entrance exams, High stakes testing, Science curriculum, Transition from Primary to Secondary Education (TEOG) Exam

\section{Introduction}

For almost 60 years (Hurd, 1958), it has been assumed that one of the fundamental objectives of science courses has been the development of scientifically literate individuals (deBoer, 2000; Hurd, 1998; Sullivan, 2008). Within the context of the Turkish Ministry of National Education (TMoNE, 2005), scientific literacy has been equated with processing skills such as investigating, inquiring, critical thinking,problem-solving, and lifelong learning. Science curricula introduced in Turkey in 2005 and 2013 emphasized the need for scientifically literate individuals who possessed science process skills (SPS), and the Turkish science curriculum draft published in 2017 included SPS in two of its general objectives (TMoNE, 2017). The 2005 science curriculum defined SPS regarding skills often used by scientists. If you think about SPS in the absence of the context of science, however, they look like the logical and rational thinking steps involved in the human endeavor of solving problems (Harlen, 1999).

According to Gillies and Nichols (2014), science process skills support critical and scientific thinking skills of students. They also help students develop a perspective on the nature of science that is more "scientific" (Williams et al., 2004). Moreover, they are essential for establishing a context where the students can discover learning (Abruscato, 2000). By providing students with a better understanding of how scientists think and work, science process skills can be advantageous for students (Martin, 2012). Individual science process skills can be applied to an activity or task, or they can be used in combination. While using the SPS associated with classification or inferring, for example, the student may also use an observation SPS (Ostlund, 1992). 
For this study, commonly accepted SPSs were divided into the two groups shown in Table 1: basic process skills and integrated process skills (Martin, 2012).

Table 1. Science process skills and their definitions

\begin{tabular}{|c|c|c|}
\hline \multicolumn{3}{|c|}{ Basic Science Process Skills } \\
\hline & Observation & $\begin{array}{l}\text { Complete, detailed, accurate statement and/or picture of } \\
\text { the observed thing usually constructed by using the senses } \\
\text { (Checkovich \& Sterling, 2001; Padilla, 1990). }\end{array}$ \\
\hline 2 & Comparison and Classification & $\begin{array}{l}\text { Grouping things according to their similarities or } \\
\text { differences. }\end{array}$ \\
\hline & Prediction & $\begin{array}{l}\text { Predicting a future observation or event based on } \\
\text { observations, measurements, and inferences and answers } \\
\text { the question: What might happen? (Abruscato, 2000). An } \\
\text { educated guess about the expected outcome of an event, } \\
\text { activity or so on (Baxter \&Kurtz, 2001). }\end{array}$ \\
\hline 4 & Assessment & $\begin{array}{l}\text { Comparing objects by using a standard or non-standard } \\
\text { unit (Ostlund, 1992). }\end{array}$ \\
\hline & Data Recording & $\begin{array}{l}\text { Recording collected data after they have been organized } \\
\text { (Çepni, Ayas, Johnson \& Turgut, 1997). }\end{array}$ \\
\hline 6 & Inference & Predicting why a specific event happened (Martin, 2012). \\
\hline 7 & Number and Space Correlations & $\begin{array}{l}\text { Making numeric correlations, estimating and interpreting } \\
\text { mathematical statements, and/orunderstanding three- } \\
\text { dimensional spatial processes (Temiz \% Tan, 2003). }\end{array}$ \\
\hline \multicolumn{3}{|c|}{ Integrated Skills } \\
\hline & Data Processing and Modeling & $\begin{array}{l}\text { Organizing data collected through experiment; and } \\
\text { symbolizing data in mental, visual or physical terms. } \\
\text { (Ostlund, 1992). }\end{array}$ \\
\hline & Variable Identification & $\begin{array}{l}\text { Identifying the elements of an event that change or do not } \\
\text { change in different situations (Çepni et al., 1997). }\end{array}$ \\
\hline & Experiment Designing & $\begin{array}{l}\text { Making use of observations to identify and conduct } \\
\text { reasonable ways to test an idea or a hypothesis (Chiappetta } \\
\text { \& Koballa, 2010). }\end{array}$ \\
\hline & Interpretation and Inference & $\begin{array}{l}\text { Offering explanations or suggestions based on the results } \\
\text { of the experiment }\end{array}$ \\
\hline & Formulating Hypothesis & $\begin{array}{l}\text { Making predictions and generalizations about an event or } \\
\text { situation based on experiences, thinkingabout why } \\
\text { something will happen. (Padilla, 1990; Çepni et al., 1997) } \\
\text { An educated guess about why the outcomes occurred - a } \\
\text { temporary statement (Baxter \& Kurtz, 2001) }\end{array}$ \\
\hline
\end{tabular}

The SPS listed above can be closely related and complement each other (Baird \& Borich, 1987; Roth \&Roychoudhury, 1993). However, a long, systematic process of epistemic development is necessary for students to develop a complete set of these skills. It is therefore vital for both national and international exams to include these skills to determine the level at which such skills have been acquired by students (Harlen, 1999). Thus, the Trends in International Mathematics and Science Study (TIMSS) and the Program for International Student Assessment(PISA) examinations have SPS integrated into the questions they ask (Mullis et al.,2003; OECD, 1999).The inclusion of SPS in curricula (Saban, Aydogdu \& Elmas, 2014), exams (Akinbobola, \& Afolabi, 2010; Ongowo \& Indoshi, 2013), textbooks (Saban, Aydogdu \& Nakiboglu, 2016; Şen \& Nakiboğlu, 2014) and other educational materials and contextshave all been studied (Şahin, Aydın \& Yurdakul, 2016;Elmas \& Geban, 2016). 
It is useful to differentiate between "high-stakes" and "low-stakes" tests or examinations (Amrien \& Berliner, 2002). High-stakes national exams are used in many countries to determine whether individual students are ready for admission to high schools. In other countries, such as the United States, low-stakes tests are used to gain insight into the skills a state-wide or national sample of students can exhibit at a particular age- or grade-level. In Turkey, the high-stakes exam abbreviated as TEOG is used for admission into the high school. Because science process skills are part of the science curricula, they should be included in TEOG exams, as well.

TEOG exams consist of multiple-choice questions and are given to $8^{\text {th }}$-grade students in the form of two examination sessions and two make-up examinations administered in the first and second semesters of the academic year. There are 120 questions on a TEOG examination, 20 of which focus on science and technology (TMoNE, 2016). If science process skills are one of the primary objectives of the curriculum, it is essential to identify the level at which these skills are measured in the science and technology questions included in the TEOG exams each year. The goal of this paper is, therefore, an analysis of the SPS in the science and technology questions in recent TEOG exams.

\section{Method}

Qualitative research techniques based on document analysis (Patton, 2014) were used to investigate the written materials associated with the science and technology portion of recent TEOG exams. The document analysis process was applied to science and technology questions from 12 TEOG examinations administered over the course of three years, from 2013 to 2016. Because each of the four exams administered each year contains 20 science and technology questions, we started with 80 questions from each year. One question from 2013-2014 and one question from 2015-2016 were considered invalid, leaving 238 questions in the sample.

The framework for document analysis in Table 2 used guiding statements developed by Saban, Aydoğdu, and Nakiboğlu (2016) that enable the identification of the science process skills in the questions in the sample. In the development of this framework, some definitions of SPS from the literature were used (Abruscato, 2000; Çepni et al., 1997; Martin, 2012; Şen \& Nakiboğlu, 2014). Other definitions were based on the 2005 science curriculum because the SPS involved in the 2013 science curriculum were not explicitly stated (Saban, Aydogdu \& Elmas, 2014).

Table 2. The framework used in the analysis of TEOG science and technology questions

\begin{tabular}{ll}
\hline Skill & Statement \\
\hline Observation & $\begin{array}{l}\text { Observe. What do you see, hear? How would you define that?Please } \\
\text { describe, tell about the change, find the differences, state features such } \\
\text { as color, smell, size, etc., state the properties, state the changes. }\end{array}$ \\
\hline Assessment & $\begin{array}{l}\text { Compare, count, state the dimensions, tell the ways of determining the } \\
\text { dimensions, weight, length, etc. State the appropriate measurement } \\
\text { tool, state its units, describe the measurement tool, state the } \\
\text { measurable properties, convert from one unit to another. }\end{array}$ \\
\hline Comparison and & $\begin{array}{l}\text { State the similarities, differences and common properties needed to } \\
\text { group things as bigger, smaller, wetter, harder, softer, etc. Compare, } \\
\text { group, classify based on properties }\end{array}$ \\
\hline Data Recording & $\begin{array}{l}\text { Record, report, note, mark, state the data in writing, on the table, } \\
\text { form,etc. }\end{array}$ \\
\hline Prediction & $\begin{array}{l}\text { What would you think would happen if something else happens? } \\
\text { State, predict what might happen, what would affect most? }\end{array}$ \\
\hline Inference & $\begin{array}{l}\text { State the cause of a particular result, state the reasons for this result. } \\
\text { You saw ......, what do you infer from that? What are your reasons for }\end{array}$ \\
\hline
\end{tabular}




\begin{tabular}{|c|c|}
\hline & such inference? \\
\hline $\begin{array}{l}\text { Interpretation and } \\
\text { Concluding }\end{array}$ & $\begin{array}{l}\text { What does it mean? Comment on it, discuss the correlation, What can } \\
\text { you tell based on the results? Describe (comment on) the graphic. }\end{array}$ \\
\hline $\begin{array}{l}\text { Number and Space } \\
\text { Correlations }\end{array}$ & $\begin{array}{l}\text { How many dimensions does it have? What's its symmetry? How do we } \\
\text { convert the form to dimension...? Convert, calculate, comment on the } \\
\text { graphic. }\end{array}$ \\
\hline $\begin{array}{l}\text { Data Processing and } \\
\text { Modeling }\end{array}$ & $\begin{array}{l}\text { Present the result in graphic, table, photo, etc. Draw, state, design the } \\
\text { model }\end{array}$ \\
\hline Experiment Designing & $\begin{array}{l}\text { Design, create or suggest a mechanism. } \\
\text { How do we test the hypothesis? What could be added, changed at } \\
\text { stage....? How would you design, perform the experiment? }\end{array}$ \\
\hline Variable Identification & $\begin{array}{l}\text { Describe the correlation between A and B. How does A affect B? What } \\
\text { does A depend on? When A was ..., what happened to B? How would } \\
\text { it change depending on ....? Perform ... controlled experiment(s). }\end{array}$ \\
\hline $\begin{array}{l}\text { Formulating } \\
\text { Hypothesis }\end{array}$ & $\begin{array}{l}\text { Develop a hypothesis based on the problem. How shall hypothesis } \\
\text {...be developed according to variables... If ....., what would happen? }\end{array}$ \\
\hline
\end{tabular}

Three researchers used this framework during six meetings to analyze the 238 valid science and technology questions in TEOG examinations between 2013 and 2016. A skill-based analysis was applied to each question to identify the SPS involved in the question. During the analysis process, each question was solved, the area of the question was determined (biology, chemistry, physics), and the science process skills involved in answering the question were determined. Any disagreements were discussed in detail until an agreement was achieved, which provided a basis for similar situations. The researchers agreed, for example, that the skill of designing an experiment was a combination of several skills (Çepni et al., 1997; Temiz \& Tan, 2003), including the skill of identifying variables. The level of agreement among the researchers was 90\% (Miles, Huberman \& Saldana, 2013). The following provides examples of the analysis of four questions:

1. Question 16 from the TEOG given in the first semester of the 2013-2014 academic year asked the students which measurement tools (thermometer, ruler, graduated cylinder, scale) had to be used to determine the density of the material. Because the question said: "... state the appropriate measurement tool ..." the question was classified as an example of the assessment process skill.

2. Question 1 from the first term of the 2014-2015 academic year listed three species and the number of chromosomes they contained. The choices listed four different species and the number of chromosomes they contained. The question required the students to determine the species in the statement of the question and the answers that had the same number of chromosomes. Because of the nature of the question, students do not have to identify, compare or classify anything. They only have to check to see which species have the same number of chromosomes. The researchers, therefore, concluded that none of the SPS in Table 2 were involved. If an SPS is associated with this question, it would be pattern recognition, but the correct answer canbe found without any explicit use of this SPS.

3. Question 5 from the second term of the 2015-2016 academic year noted that a germinating bean and limewater were put into the first of two identical jars and only limewater was put into the other jar and that limewater became cloudy in the presence of carbon dioxide. The students were asked to identify the statement about the experiment that was true. The choices included statements about different variables in the experiment, potential situations that could be observed, and the purpose of the experiment. Although one of the choices could be 
associated with the variable identification skill, the researchers concluded that the question involved the experiment designing skill.

4. Question 5 from the first term of the 2015-2016 academic year described the strategy the seahorse developed to both hunts and protect itself from predators. The students were asked: To which way of living does this correspond? Because students had to use both the comparison/classification and the interpretation and concluding skill, the question was included in both categories of SPS.

After the questions were analyzed, two different TEOG examinations were sent to two science lecturers from different universities to see how they would analyze the questions and their recommendations were incorporated to increase the validity of the analysis (Patton, 2014).

\section{Results}

Table 3 presents the overall results of the document analysis process. The left column contains the list of science process skills, and the top row identifies the TEOG exam that was analyzed. For each year, results are given from the first $\left(E_{1}\right)$ and second $\left(E_{2}\right)$ semester TEOG exam and the first $\left(E_{1}\right)$ and second ( $\mathrm{EE}_{2}$ ) semester make-up exam. The far-right column of this table lists the total number of times questions classified as exhibiting individual SPS were found among the science and technology questions on the 12 exams that were analyzed.

Table 3. Analysis of S\&T questions in TEOG examinations concerningSPSs.

\begin{tabular}{|c|c|c|c|c|c|c|c|c|c|c|c|c|c|c|}
\hline \multicolumn{14}{|c|}{ Years } & \multirow{3}{*}{ Total } \\
\hline & & & 2013 & 201 & & & 2014 & 2015 & & & 2015 & 2016 & & \\
\hline \multicolumn{2}{|c|}{$\begin{array}{l}\text { Science } \\
\text { Process Skills }\end{array}$} & $\mathrm{E}_{1}$ & $\mathrm{EE}_{1}$ & $\mathrm{E}_{2}$ & $\mathrm{EE}_{2}$ & $\mathrm{E}_{1}$ & $\mathrm{EE}_{1}$ & $\mathrm{E}_{2}$ & $\mathrm{EE}_{2}$ & $\mathrm{E}_{1}$ & $\mathrm{EE}_{1}$ & $\mathrm{E}_{2}$ & $\mathrm{EE}_{2}$ & \\
\hline \multirow{8}{*}{ 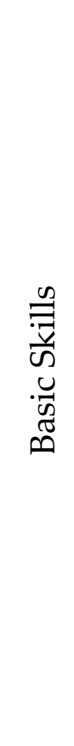 } & Comparison \& & & & & & & & & & & & & & \\
\hline & Classification & 1 & 2 & 2 & - & - & 1 & 2 & 1 & 2 & 1 & 1 & 1 & 14 \\
\hline & Prediction & 1 & 1 & 1 & - & 1 & 3 & - & 1 & 1 & 2 & - & 3 & 14 \\
\hline & Assessment & 5 & 1 & - & - & 5 & - & - & - & 2 & 3 & - & - & 16 \\
\hline & Inference & 1 & 1 & 1 & 2 & 1 & 3 & 4 & 1 & 6 & 3 & 1 & 5 & 29 \\
\hline & $\begin{array}{l}\text { Number \& } \\
\text { Space }\end{array}$ & & & & & & & & & & & & & \\
\hline & Correlations & 1 & - & 3 & 1 & - & - & 3 & 3 & - & - & 3 & 3 & 17 \\
\hline & Total & 9 & 5 & 7 & 3 & 7 & 7 & 9 & 6 & 11 & 9 & 5 & 12 & 90 \\
\hline \multirow{2}{*}{ 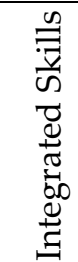 } & $\begin{array}{l}\text { Data } \\
\text { Processing \& } \\
\text { Modelling }\end{array}$ & - & - & - & - & - & 2 & - & - & - & - & - & - & 2 \\
\hline & $\begin{array}{l}\text { Variable } \\
\text { Identification }\end{array}$ & - & - & 1 & 2 & - & - & - & 1 & 1 & - & 1 & 4 & 10 \\
\hline
\end{tabular}




\begin{tabular}{|c|c|c|c|c|c|c|c|c|c|c|c|c|c|}
\hline $\begin{array}{l}\text { Experiement } \\
\text { Designing }\end{array}$ & - & 1 & 1 & 1 & 2 & - & 4 & 1 & - & - & 3 & 2 & 15 \\
\hline $\begin{array}{l}\text { Formulating } \\
\text { Hypothesis }\end{array}$ & - & - & 2 & - & - & - & - & - & - & - & - & - & 2 \\
\hline $\begin{array}{l}\text { Interpretation } \\
\text { Inference }\end{array}$ & 7 & 7 & 1 & 2 & 2 & 6 & 3 & 3 & 12 & 9 & 2 & 5 & 59 \\
\hline Total & 7 & 8 & 5 & 5 & 4 & 8 & 7 & 5 & 13 & 9 & 6 & 11 & 88 \\
\hline General Total & 16 & 13 & 12 & 8 & 11 & 15 & 16 & 11 & 24 & 18 & 11 & 23 & 178 \\
\hline
\end{tabular}

Table 3 indicates that TEOG science and technology (S\&T) questions involved interpretation/inference process skills far more often $(n=59)$ than any other SPS and the data processing/modeling process skills $(n=2)$ and formulating a hypothesis $(n=2)$ far less often. The use of science processing skills then increased in the following order: variable identification $(n=10)$, comparison/classification $(\mathrm{n}=$ $14)$, prediction skills $(n=14)$, experiment designing $(n=15)$ times, assessment $(n=16)$, number and space correlation $(n=17)$, and interpretation/inference $(n=29)$. It is interesting to note that neither the observation nor data recording skills were involved in any of the 238 questions analyzed. Because more than one SPS could be associated with a given question, science processes skills were found 178 times in 161 of the 238 S\&T questions. Within the sample population of 238 questions, one SPS was found in 144 questions and two SPS in 17 questions.

Table 4 contains the number of questions from among the 20 science and technology questions on each TEOG examination that included one SPS and the number that contained two.

Table 4. The number of questions from each TEOG that included SPS once or twice.

\begin{tabular}{cccc}
\hline \multirow{2}{*}{$\begin{array}{c}\text { Academic } \\
\text { Year }\end{array}$} & Exam & $\begin{array}{c}\text { The number of questions } \\
\text { that included one SPS }\end{array}$ & $\begin{array}{c}\text { The number of } \\
\text { questions that } \\
\text { included two SPS }\end{array}$ \\
\hline \multirow{3}{*}{$2013-2014$} & E1 & 14 & 1 \\
\cline { 2 - 4 } & EE1 & 11 & 1 \\
\cline { 2 - 4 } & E2 & 12 & - \\
\hline & EE2 & 8 & - \\
\hline \multirow{3}{*}{$2014-2015$} & EE1 & 11 & 1 \\
\cline { 2 - 4 } & E2 & 13 & 1 \\
\cline { 2 - 4 } & EE2 & 14 & - \\
\hline \multirow{3}{*}{$2015-2016$} & EE1 & 11 & - \\
& E2 & 10 & 5 \\
\cline { 2 - 4 } & EE2 & 16 & - \\
\hline
\end{tabular}

The total number of basic science process skills $(n=90)$ in the 12 TEOG exams was similar to the total number of integrated science process skills $(n=88)$. Because the number of SPS in the basic skills groups is the same as in the integrated skills group, the difference between the average frequency of occurrence of the basic skills (18.0) and integrated skills (17.6) is not significant.

Results on Yearly Basis 
Figure 1 shows the total number of SPS in TEOG S\&T questions and the number of S\&T questions involving science process skills each year from 2013 through 2016. The total number of SPS per year increased from 49 to 76 , and the number of questions that were associated with science process skills increased from 47 to 63 . Whereas there is insufficient data to suggest that either of these patterns will continue, the fact that they are both going in the same direction suggests that progress is being made in increasing the incorporation science process skills into the TEOG science and technology questions.

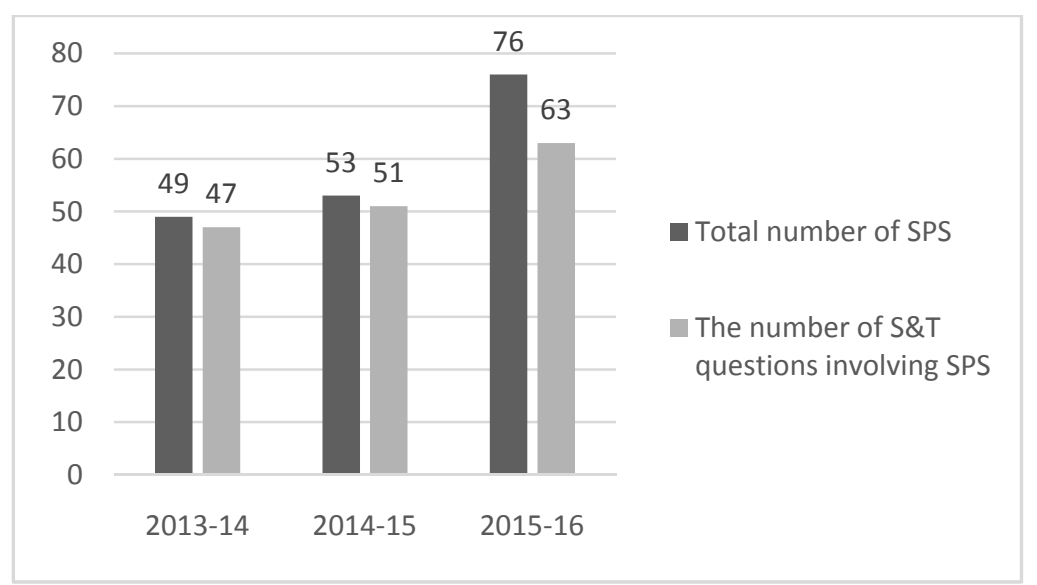

Figure 1. Total number of SPS and the number of S\&T questions involving science process skills each year from 2013 through 2016

\section{Distribution of SPS by Science and Technology Fields}

Table 5 shows the distribution of TEOG S \& T questions concerning biology, chemistry, and physics.

Table 5.Distribution of SPS and TEOG S\&T questions concerningfield.

\begin{tabular}{lccc}
\hline Discipline & Biology & Chemistry & Physics \\
\hline $2013-2014$ & 28 & 27 & 24 \\
\hline $2014-2015$ & 26 & 10 & 44 \\
\hline $2015-2016$ & 32 & 8 & 39 \\
\hline Total Questions & 86 & 45 & 107 \\
\hline $\begin{array}{l}\text { Total number of } \\
\text { questions included SPS }\end{array}$ & 59 & 27 & 92 \\
\hline ASPS & 0.68 & 0.60 & 0.80 \\
\hline
\end{tabular}

*Academic Year

** ASPS; Average Science Process Skills: The number of SPS identified in each field (biology, chemistry, and physics) divided by the number of questions from that field.

Table 5 demonstrates an uneven distribution of questions from the three fields of science covered by this exam; 86 of the 238 Science and Technology questions analyzed in this study were from biology, 45 were from chemistry, and 107 from physics. There was also an uneven distribution of SPS in these fields. One-third (33.2\%) of the SPS was associated with biology questions, slightly more than one-half $(51.7 \%)$ with physics questions, and less than one-sixth (15.2\%) with chemistry. The average number of science process skills for each field was calculated by dividing the number of questions by the 
number of SPS found in the analysis of the TEOG questions. This ratio was significantly larger in physics (0.86) than either biology (0.68) or chemistry (0.60). These results can be compared with the overall average for the TEOG exams by noting that SPSs were found in 161 of the 238 questions $(67.6 \%)$ and that 178 SPSswere identified in these questions for an overall average science process skill score of 0.74 .

\section{Discussion and Conclusions}

The results obtained in this study suggest that science process skills are often involved in answering the science and technology questions on the TEOG examination, inmuch the same way that they are embedded in science curriculum (TMoNE, 2005; TMoNE, 2013) and in draft programs (TMoNE, 2017) proposed in recent years.Although no prior research exists that looks at the relationship between SPS and the TEOG exams, Özden et al. (2014) studied TEOG examination S\&T questions concerning their fit with the acquisition of the lesson based on the "Depth of Knowledge" system. They noted that only $15 \%$ of the questions were able to assess the integrated science process skills, and concluded that TEOG failed to live up to expectations concerning the assessment of integrated skills. In the qualitative part of their research, Şad and Şahiner (2016) stated that 6 of $178^{\text {th }}$-grade students, parents, and teachers who participated in their study believed that the types of multiple-choice questions used in TEOG examinations made it difficult to have a valid and reliable assessment ofintegrated thinking skills.

There is evidence that high-stakes testing and a multiple-choice format are incompatible in some contexts (Au, 2007; Barksdale-Ladd \& Thomas, 2000). There are also studies that suggest that PISA and TIMMS exams are not reporting reliable results because of the question format, and quality, contextual, and cultural differences of each country in the sample group (Eivers, 2010; Harlow \& Jones, 2004; Rutkowski \& Rutkowski, 2013; Wuttke, 2007). Open-ended items can have some advantages over multiple-choice questions because they eliminate random guessing, but questions with open-ended answers take more time to administer and considerably more resources to review (Bridgeman, 1992). In the end, multiple-choice question formats for high-stakes testing may be the most convenient, fair, and inexpensive way to judge an individual's level of performance or readiness for the next step in the educational system. When they are used, however, it is essential that highquality questions be used to measure a given construct or educational outcome (Elmas \& Eryilmaz, 2015; Haladyna, 1999; Haladyna, Downing \& Rodriguez, 2002).

In this study, it was interesting to note that no questions that involved either observation or dataprocessing skills could be found on the TEOG exams, perhaps because of the difficulty of incorporating these SPS into multiple-choice questions. Although no prior research that addressed the presence of SPS in national high-school entrance exams was found, Demir (2007) noted that math scores obtained on university entrance examinations had no direct impact on the science process skills of pre-service teachers.

This study noted that SPS that involved interpretation/inference skills occurred most often on the TEOG questions, whereas data-processing/modeling skills were seldom associated with these questions. Because interpretation/inference skills play a particularly important role in students' development of science process skills (Çepni et al. 1997), the frequency with which they are associated with TEOG S\&T questions may be appropriate. On the other hand, science process skills such as formulating hypotheses and data-processing/modeling should occur more often, for many reasons. In part, because integrated science processing skills may be inherently more important than basic skills in a student's epistemic development. In part, because they can play an important role in the development of the student's problem-solving abilities (Aktamış \& Ergin, 2007). Moreover, in part, 
because they can play an essential role in the student's ability to design experiments on their own (Şen \& Nakiboğlu, 2014).

In this study, the number of examples of basic skills $(n=90)$ was virtually the same as integrated skills $(n=88)$. This might be appropriate for a low-stakes exam whose goal is to provide a picture of the state of epistemic development in general, at a particular age- or grade-level. However, the TEOG is a high-stakes exam intended to measure an individual's potential for entrance to secondary education, which may mean that integrated process skills should appear more often than they do. It might, therefore, be useful to compare the results of this study with analogous work on high-stakes exams in other countries. In a study of secondary-education biology, practical exams in Kenya over a period of ten years, considerably more basic skills $(73.7 \%)$ than integrated skills $(26.3 \%)$ were identified (Ongowo \& Indoshi, 2013). A similar study of physics questions in Nigeria also found considerably more basic skills (62.8\%) than integrated skills (37.2\%) (Akinbobola, \& Afolabi, 2010).

While considering the balance between basic and integrated process skills in the TEOG, it might be useful to note that some researchers have argued that basic skills be mainly involved in primary schools, whereas the integrated skills are mainly involved in secondary and high schools (Ferreira, 2004). Similarly, a study conducted by Bağcı-Kılıç, Haymana, and Bozyılmaz (2008) of the 2005 science and technology curriculum noted that the curriculum involved more basic than integrated process skills. Others have argued that the integrated skills be a combination of basic process skills (Padilla, 1990; Şen \& Nakiboğlu, 2014). It has also been argued that these two groups of process skills complement each other (Çepni et al. 1997) and that students need integrated skills, such as experiment designing and variable identification, to solve problems (Bağcl-Kılıç, Haymana \& Bozyılmaz, 2008).

In this study, questions that involved one SPS $(n=144)$ far outnumbered those that involved two SPS $(n=17)$. It is therefore interesting to note that Aktamış and Şahin-Pekmez (2011) have argued that different types of questions - such as multiple-choice versus open-ended - might match different SPS and therefore enable a more comprehensive assessment. This is consistent with the observation that multiple-choice questions were more likely to focus on primarily one skill (Aktamış \& Şahin-Pekmez, 2011; Aydogdu, Tatar, Yildiz \& Buldur, 2012), whereas certain open-ended questions involved more than one skill (Aktamış \& Şahin-Pekmez, 2011). The results obtained by the analysis of the multiplechoice questions used in the TEOG are therefore consistent with prior work.

Increasing efforts to include the assessment of science process skills in the TEOG examinations could convince teachers to emphasize these skills in their assessments (Şahin, Aydın \& Yurdakul, 2016). It could do this by influencing their intrinsic motivation by providing examples of such questions. Alternatively, through extrinsic motivation related to the observation that teachers are anxious about their students getting high scores in TEOG examinations (Şad \& Şahiner, 2016).Consider the work of Capp (2009), for example, in which an instructional activity for $5^{\text {th-grade }}$ students based on the process skill of determining the validity of an experiment was introduced to help students "... make connections between a science process (validity) and the kind of questions on state-mandated tests." Capp noted that introducing this activity lead to a $10 \%$ increase in the students' state standardized test scores compared to previous year's scores.

Increasing the emphasis on SPS could support the performance of more activities and an increased focus on skill development in class (Çepni et al. 1997). Because SPS foster both creating knowledge and focusing on knowledge (Temiz \& Tan, 2003), the involvement of these skills in examinations could have a beneficial effect by reducing student anxiety about these exams.

Increasing the role of SPS in TEOG exams could also have a long-term effect on performance on international exams. The PISA exam, for example, emphasizes scientific literacy and one of the most 
significant variables of scientific literacy is the SPS. When Turkey entered into PISA for the first time in 2003, it had a mean score of 434 in science. In PISA-2015 the mean score was 425 . Considering that SPS help students transfer things learned in a science lesson to daily life, the increased involvement of SPSs in the curriculum since 2005 is expected to have along-term positive impact on scientific literacy levels of students (Anagün, 2011), which can affect the results of both international examinations and TEOG examinations in a positive way.

\section{Acknowledgements}

The first author of this paper is a visiting scholar at Purdue University, and he is supported by 2219 program of Scientific and Technological Research Council of Turkey (TUBITAK).

\section{References}

Abruscato, J. (2000). Teaching children science: A discovery approach (5th Ed.). Boston: Allyn and Bacon.

Akinbobola, A. O., \& Afolabi, F. (2010). Analysis of science process skills in West African senior secondary school certificate physics practical examinations in Nigeria. American-Eurasian Journal of Scientific Research, 5(4), 234-240.

Aktamış, H. ve Ergin, Ö. (2007). Investigating the relationship between science process skills and scientific creativity. Hacettepe University Journal of Education, 33, 11-23.

Aktamış, H. ve Şahin-Pekmez, E. (2011). A Study of developing scientific process skills inventory towards science and technology course. Buca Faculty of Education Journal, 30, 192-205.

Amrein, A. L., \& Berliner, D. C. (2002). High-stakes testing \& student learning. Education policy analysis archives,10, 18.berliner Anagün, Ş. S. (2011). The impact of teaching-learning process variables to the students' scientific literacy levels based on PISA 2006 results. Education ve Science, 36 (162), 84-102.

$\mathrm{Au}, \mathrm{W}$. (2007). High-stakes testing and curricular control: A qualitative meta-synthesis. Educational Researcher, 36(5), $258-267$.

Aydoğdu, B., Tatar, N., Yıldız, E., \& Buldur, S. (2012). Developing a science process skills scale for elementary students. Journal of Theoretical Educational Science, 5(3), 292-311.

Bağcl-Kılıç, G. B., Haymana, F. ve Bozyılmaz, B. (2008). Analysis of the Elementary Science and Technology Curriculum of Turkey with respect to different aspects of scientific literacy and scientific process. Education ve Science, 33(150), 52-63.

Baird, W. E., \& Borich, G. D. (1987). Validity considerations for research on integrated science process skills and formal reasoning ability. Science Education, 71(2), 259-269.

Barksdale-Ladd, M. A., \& Thomas, K. F. (2000). What's at stake in high-stakes testing: Teachers and parents speak out. Journal of Teacher Education, 51(5), 384-397.

Baxter, L. M., \& Kurtz, M. J. (2001). When a hypothesis is not an educated guess. Science and Children, 38(7), 18.

Bridgeman, B. (1992). A Comparison of Quantitative Questions in Open-Ended and Multiple-Choice Formats. Journal of Educational Measurement, 29(3), 253-271.

Capp, R. (2009). Process skills practice and standardized tests. Science and Children, 46(5), 28-30.

Checkovich, B. H., \& Sterling, D. R. (2001). Oh say can you see. Science and Children, 38(4), 32.

Chiappetta, E. L. ve Koballa, T. R. (2010). Science instruction in the middle and secondary schools: Developing fundamental knowledge and skills for teaching. (7th Ed.) Columbus, OH: Pearson.

Çepni, S., Ayas, A., Johnson, D., \& Turgut, M. F. (1997). Physics teaching (Fizik öğretimi). Ankara: YÖK/Dünya Bankası Milli Eğitimi Geliştirme Projesi, Hizmet Öncesi Öğretmen Eğitimi. Retrieved from http://www.hskizilcik.com/fizik/egitim/FizikOgretimi.pdf

DeBoer, G. E. (2000). Scientific literacy: Another look at its historical and contemporary meanings and its relationship to science education reform. Journal of Research in Science Teaching, 37(6), 582-601.

Demir, M. (2007). Determining the factors affecting the qualifications of the classroom teacher candidates regarding scientific process skills (Sınıf öğretmeni adaylarının bilimsel süreç becerileriyleilgiliyeterliklerinietkileyen faktörlerin belirlenmesi). (Unpublished Ph.D. Thesis). Gazi University, Ankara, Turkey.

Eivers, E. (2010). PISA: Issues in implementation and interpretation. The Irish Journal of Education/Iris Eireannach an Oideachais, 94-118.

Elmas, R., \& Eryilmaz, A. (2015). How to Write Good Quality Contextual Science Questions: Criteria and Myths. Journal of Theoretical Educational Science, 8(4), 564-580.

Elmas, R., \& Geban, Ö. (2016). The Effect of Context Based Chemistry Instruction on 9th Grade Students' Understanding of Cleaning Agents Topic and Their Attitude Toward Environment. Education and Science, 41(185), 33-50.

Ferreira, L. B. M. (2004). The role of a science story, activities, and dialogue modeled on philosophy for children in teaching basic science process skills to fifth graders. (Unpublished Ph.D. Thesis). Montclair State University, New Jersey, USA.

Gillies, R. M., \& Nichols, K. (2015). How to support primary teachers' implementation of inquiry: Teachers' reflections on teaching cooperative inquiry-based science. Research in Science Education, 45(2), 171-191.

Haladyna, T. M. (1999). Developing and validating multiple-choice test items. Mahwah, NJ: Lawrence Erlbaum Associates, Inc.

Haladyna, T. M., Downing, S. M., \& Rodriguez, M. C. (2002). A review of multiple-choice item-writing guidelines for classroom assessment. Applied Measurement in Education, 15(3), 309-333. 
Harlen, W. (1999). Purposes and procedures for assessing science process skills. Assessment in Education: principles, policy \& practice, 6(1), 129-144.

Harlow, A., \& Jones, A. (2004). Why students answer TIMSS science test items the way they do. Research in Science Education, 34(2), 221-238.

Hurd, P. (1958). Science literacy: Its meaning for American schools. Educational Leadership, 16(1), 13-16.

Hurd, P. D. (1998). Scientific inquiry: New minds for a changing world. Science Education, 82(3), 407-416.

Martin, D. J. (2012). Elementary Science Methods: Constructivist Approach (6. Edition). USA: Cengage Learning.

Miles, M. B., Huberman, A. M., \& Saldana, J. (2013). Qualitative data analysis. California: Sage.

Mullis, I. V. S., Martin, M. O., Smith, T. A., Garden, R. A., Gregory, K. D., Gonzalez, E. J., Chrostowski, S. J. \& O’Connor, M. K. (2003). TIMSS Assessment Frameworks and Specifications 2003. International Study Center, Lynch School of Education, Boston College. Retrieved from http://repositorio.minedu.gob.pe/bitstream/handle/123456789/4340/TIMSS\%20Trends\%20in\%20Mathematics\%20and $\% 2$ 0Science\%20Study\%20Assessment\%20Frameworks\%20and\%20Specifications\%202003.pdf?sequence=1\&isAllowed=y

OECD (1999). Measuring Student Knowledge and Skills: A New Framework for Assessment. Retrieved from https://www.oecd.org/edu/school/programmeforinternationalstudentassessmentpisa/33693997.pdf

Ongowo, R. O., \& Indoshi, F. C. (2013). Science process skills in the Kenya certificate of secondary education biology practical examinations. Creative Education, 4(11), 713-717.

Ostlund, K. L. (1992). Science process skills: assessing hands-on student performance. New York: Addison-Wesley.

Padilla, M. J. (1990). The science process skills. Research Matters-to the science Teacher, 9004. Retrieved from https://www.narst.org/publications/research/skill.cfm

Patton, M. (2014). Qualitative evaluation \& research methods (4th Edition). USA: SAGE Pub.

Roth, W. M., \& Roychoudhury, A. (1993). The development of science process skills in authentic contexts. Journal of Research in Science Teaching, 30(2), 127-152.

Rutkowski, D., \& Rutkowski, L. (2013). Measuring socioeconomic background in PISA: One size might not fit all. Research in Comparative and International Education, 8(3), 259-278.

Saban, Y., Aydoğdu, A. ve Elmas, R. (2014). The Comparison of 2005 and 2013 Science Curricula for Science Process Skills in 4th and 5th Grades (2005 ve 2013 Fen Bilgisi Dersi Öğretim Programlarımın 4 ve 5. Sınıf Düzeylerinin Bilimsel Süreç Becerileri Açısından Karşılaştırılması). Mehmet Akif Ersoy University Faculty of Education Journal, 32, 62-85.

Saban, Y., Aydoğdu, B. ve Nakiboğlu, C. (2016). Analysis of 3 and 4 th grade science text books regarding their inclusion of SPS (3 ve 4. sınıf fen bilimleri ders kitaplarının bilimsel süreç becerileri açısından incelenmesi). 15. International Classroom Teacher Education Semposium.Muğla, Turkey.

Sullivan, F. R. (2008). Robotics and science literacy: Thinking skills, science process skills and systems understanding. Journal of Research in Science Teaching, 45(3), 373-394.

Şad, S. N. ve Şahiner, Y. K. (2016). Students' Teachers' and Parents' Views about Transition from Basic Education to Secondary Education (BESE) System (Temel eğitimden ortaöğretime geçiş (TEOG) sistemine ilişkin öğrenci, öğretmen ve veli görüşleri). Elementary Education Online, 15(1), 53-76.

Şahin, S., Aydın, S. Ö. ve Yurdakul, B. (2016). Seventh Grade Science and Technology Course Evaluation Activities in the unit of Human and Environment According to the Science Process Skills (Fen ve teknolojidersi öğretim programı yedinci sınıf insan ve çevre ünitesindeki etkinliklerinbilimsel süreç becerileri açısından değerlendirilmesi). Necatibey Faculty of Education Electronic Journal of Science and Mathematics Education, 10 (1), 32-59.

Şen, A. Z. ve Nakiboğlu, C. (2014). Comparison of 9th-grade chemistry, physics and biology textbooks in terms of science process skills (9. sınıf kimya, fizik, biyolojiders kitaplarının bilimsel süreç becerileri açısından karşılaştırılması).Journal of Turkish Science Education,11(4), 63-80.

Temiz, B. K. ve Tan, M. (2003). The Primary Science Process Skills in Elementary School Science Teaching (Illköğretim fen öğretiminde temelbilimsel süreç becerileri). Education and Science, 28(127), 18-24.

TMoNE (Turkish Ministry of National Education) (2005). Elementary Science and Technology Curriculum. Ankara, Turkey.

TMoNE (Turkish Ministry of National Education) (2013). Elementary Science Curriculum. Ankara, Turkey.

TMoNE (Turkish Ministry of National Education) (2016). Measurement \& Evaluation, General Management of Examination Services. Retrieved from http://odsgm.meb.gov.tr/kurslar/

TMoNE (Turkish Ministry of National Education) (2017). Elementary Science Curriculum Draft. Ankara, Turkey. Retrieved from http://mufredat.meb.gov.tr/ProgramDetay.aspx?PID=106

Williams, W. M., Papierno, P. B., Makel, M. C. ve Ceci, S. J. (2004). Thinking like a scientist about real-world problems: The Cornell Institute for Research on Children Science Education Program. Journal of Applied Developmental Psychology, 25 (1), 107-126.

Wuttke, J. (2007) Uncertainties and Bias in PISA, in S.T. Hopmann, G. Brinek\& M. Retzl (Eds) PISA According to PISA. Vienna: University of Vienna. 